\title{
SEMARANG INTEGRATED BOAT RAPID TRANSIT: KAJIAN PENERAPAN TRANSPORTASI SUNGAI DI KOTA SEMARANG
}

\author{
Moh. Nur Sholeh ${ }^{*}$, Robert Fanny Al Firdaus², Dimas Sukma Adiputra² dan Sayekti Laras \\ Hidayati $^{2}$ \\ 1Dosen / Program Studi Teknik Sipil Sekolah Vokasi / Universitas Diponegoro \\ 2 Mahasiswa / Program Studi Teknik Sipil Sekolah Vokasi / Universitas Diponegoro \\ *Korespondensi: mnursholeh@lecturer.undip.ac.id
}

\begin{abstract}
ABSTRAK
Kota Semarang menjadi kota dengan jumlah penduduk yang terus meningkat. Saat ini Kota Semarang mempunyai banyak permasalahan, beberapa diantaranya adalah belum optimalnya transportasi umum dan kemacetan yang belum teratasi. Pemerintah sebagai pembuat kebijakan harus menyediakan transportasi umum yang layak untuk masyarakat. Oleh karena itu untuk memecahkan permasalahan tersebut diperlukan suatu inovasi. Tujuan dari penelitian ini adalah mengkaji terhadap Semarang Integrated Boat Rapid Transit atau Siborat sebagai bentuk inovasi transportasi sungai yang diharapkan ramah, efisien serta terintegrasi dengan transportasi lainnya. Siborat ini digunakan di sungai Banjir Kanal Timur Semarang yang menghubungkan wilayah Semarang Tengah hingga Semarang Utara. Saat ini sungai Banjir Kanal Timur digunakan untuk mengalirkan air dari tengah kota ke Laut Jawa dan sebagai bagian dari pengendalian banjir di Kota Semarang. Hasil penelitian ini menyajikan sebuah inovasi kapal dengan kapasitas 20 penumpang, estimasi waktu dan harga yang terjangkau, serta integrasi penempatan halte yang diharapkan dapat menciptakan transportasi umum yang murah dan efisien.
\end{abstract}

Kata Kunci: boat, integrated, sungai, transportasi

\section{PENDAHULUAN}

Transportasi dijadikan sebagai media dalam pemindahan barang maupun manusia dari satu tempat ke tempat lainnya dengan menggunakan sebuah alat yang digerakkan oleh mesin dengan dioperasionalkan manusia. Pergerakan ini akan memudahkan manusia dalam melakukan aktivitas sehari-hari. Jika dilihat dari fungsinya, transportasi memiliki peranan yang penting dan strategis dalam mewujudkan pembangunan nasional [1]. Hal ini terlihat dari kebutuhan mobilitas pada semua sektor dan wilayah melalui pergerakan ekonomi yang sangat cepat. Transportasi beserta modanya telah dirasakan sangat membantu dan dibutuhkan oleh semua lapisan masyarakat.

Indonesia sebagai negara kepulauan dan banyak gunung, sangat mudah untuk menjumpai sungai di setiap tempat dengan kelasnya masing-masing. Sebagai contoh
Sungai Banjir Kanal Timur (BKT) yang merupakan salah satu sungai yang membelah Kota Semarang yang digunakan sebagai pengendali banjir [2]. BKT Semarang letaknya sangat strategis karena berada di pusat kota. Selain dapat digunakan sebagai tempat pengendali banjir, Banjir Kanal Timur Semarang memiliki potensi sebagai sarana transportasi dan rantai pasok yang menghubungkan hulu dan hilir serta dapat dimanfaatkan sebagai destinasi wisata air [3]. Rantai pasok adalah aliran barang, informasi, dan uang dari hulu ke hilir [4]. Dilihat dari potensi wisata, Banjir Kanal Timur yang begitu besar maka diperlukan penelitian berkelanjutan mengenai kelayakan BKT sebagai daerah wisata baru yang menawarkan konektivitas antar beberapa daerah wisata di Kota Semarang.

Saat ini Kota Semarang menghadapi permasalahan kemacetan lalu lintas yang semakin padat terutama saat jam berangkat dan 
pulang kerja. Titik-titik kemacetan tersebut ada di wilayah Semarang bagian bawah yang menjadi pusat perindustrian dan perkantoran. Oleh karena itu perlu ada inovasi dalam mereduksi tingkat kemacetan di Kota Semarang. Tujuan dari penelitian ini adalah menganalisa kemungkinan dibuatnya transportasi sungai dengan memanfaatkan Banjir Kanal Timur di Kota Semarang yang terintegrasi dengan moda transportasi lainnya.

\section{TINJAUAN PUSTAKA}

\subsection{Kemacetan Kota Semarang}

Kemacetan merupakan suatu kondisi dimana volume arus lalu lintas yang hilir mudik pada ruas jalan yang ditinjau melebihi kapasitas rencana pada jalan tersebut. Hal ini akan mengakibatkan terjadinya antrian yang panjang karena kecepatan bebas ruas jalan tersebut mendekati $0 \mathrm{~km} / \mathrm{jam}$ atau bahkan menjadi 0 $\mathrm{km} / \mathrm{jam}$ yang berarti tidak bisa bergerak sama sekali. Antrian yang panjang dan lama akan mengakibatkan gangguan pada aktivitas manusia.

Beberapa faktor penyebab kemacetan lalu lintas yaitu:

1. Faktor kendaraan

Volume kendaraan per jam, kecepatan kendaraan dan ukuran kendaraan akan berpengaruh pada kemacetan lalu lintas.

2. Faktor manusia

Kesalahan manusia (human error) menjadi faktor penyebab kemacetan lalu lintas dikarenakan sikap dan perilaku pengemudi, pejalan kaki dan aktivitas manusia lain pada badan jalan.

3. Faktor jalan

Kondisi atau struktur permukaan jalan pada jaringan jalan akan berpengaruh pada kemacetan lalu lintas. Kondisi jalan bisa dalam bentuk berlubang, banyaknya simpangan, dan tidak adanya jalur pemisah atau kanalisasi.

4. Faktor alam

Keadaan alam yang tidak baik seperti hujan, berkabut, topografi tidak rata, dan banyaknya jalan yang melewati sungai menjadi pendorong kemacetan lalu lintas.

Kota semarang adalah kota metropolitan terbesar nomor 5 di Indonesia dengan jumlah penduduk sekitar 5,4 juta jiwa. Berdasarkan data dari Badan Pusat Statistik (BPS) [5] Kota Semarang pertumbuhan penduduk Kota Semarang naik $0,47 \%$ tiap tahunnya. Namun dibalik pertumbuhan penduduk tersebut tidak sejalan dengan penambahan lebar jalan dan transportasi umum yang mewujudkan kota metropolitan kelas dunia. Tercatat pada tahun 2016 Jumlah pengguna sepeda motor sebesar 151.290 kendaraan dan mobil sebesar 1.355 kendaraan. Keadaan seperti inilah yang menjadi salah satu penyebab utama kemacetan di Kota Semarang. Berdasarkan data dari Dinas Perhubungan Kota Semarang, menyebutkan bahwa kemacetan yang terjadi di ibu kota Jawa Tengah tersebut telah mencapai 37 jam dalam waktu setahun. Angka kemacetan ini sudah mendekati kemacetan di ibukota DKI Jakarta yang mencapai 55 jam setahun pada tahun 2016.

\subsection{Transportasi umum di Kota Semarang}

Transportasi umum pada dasarnya adalah semua aktivitas transportasi dengan menggunakan sarana angkutan secara bersama-sama dengan adanya sistem tarif yang harus dipenuhi oleh pengguna jasa dari transportasi [6]. Saat ini transportasi umum yang telah beroperasi di Kota Semarang antara lain angkutan kota, taksi, dan alat transportasi massal yang berbasis jalan yakni Bus Rapid Transit (BRT). Selain itu juga telah ada ojek online namun moda transportasi ini tidak masuk kategori transportasi umum. Justru pada momen tertentu menjadi faktor semakin macetnya jalan karena jumlah ojek online yang semakin banyak. Kedepan bisa jadi akan ada moda transportasi lain yang dikembangkan.

Moda transportasi di Kota Semarang dapat dilihat pada Gambar 1.

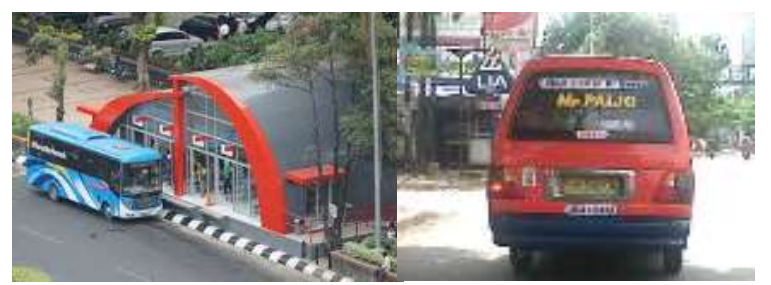

Gambar 1. Transportasi Umum di Kota Semarang

\subsection{Transportasi yang terintregasi}

Integrasi pada moda transportasi publik merupakan salah satu bentuk pengelolaan sistem transportasi publik yang mengkolaborasikan dua atau beberapa moda transportasi publik guna mewujudkan pelayanan transportasi publik yang optimal. Sistem transportasi publik pada dasarnya 
diselenggarakan dengan tujuan untuk mengkoordinasi semua aktivitas pergerakan penumpang melalui pengaturan komponenkomponen proses transportasi [7].

Berdasarkan hasil penelitian, bahwa integrasi transportasi di Indonesia belum maksimal dan baru dikembangkan di beberapa kota saja. Sistem Transportasi Nasional menyampaikan bahwa integrasi transportasi umum dijadikan sebagai sasaran utama pengembangan sistem transportasi nasional yang bertujuan untuk memberikan jaminan keamanan dan keselamatan transportasi, keteraturan, kecepatan, kelancaran, kemudahan pencapaian, kenyamanan, ketepatan waktu, ketertiban, keterjangkauan tarif, dan rendahnya tingkat polusi dalam satu kesatuan jaringan sistem transportasi publik tanpa terlalu memberikan beban kepada masyarakat. Sistem transportasi nasional tetap memberikan pelayanan yang optimal dan maksimal [8].

\subsection{Kontur Kota Semarang}

Jika dilihat dari kondisi permukaan Kota Semarang, kota ini memiliki keunikan topografi yang terbagi menjadi tiga wilayah yang sangat berbeda secara karakteristik fisiknya, yaitu perbukitan (dataran tinggi), dataran rendah, dan daerah transisi. Topografi Kota Semarang memiliki bentuk kemiringan yang beragam. 65,22\% area Kota Semarang berupa ujung-ujung pantai dan dataran rendah dengan kemiringan $25 \%$ dan sisanya $37,78 \%$, adalah daerah perbukitan dengan kemiringan $15-40 \%$.

Kota Semarang dengan kondisi lereng tanah dibagi menjadi 4 jenis kelerengan [5] yaitu lereng I (0-2\%) meliputi Kecamatan Pedurungan, Genuk, Gayamsari, Semarang Utara, Semarang Timur, Tugu, dan sebagian wilayah Kecamatan Banyumanik, Tembalang, dan Mijen. Lereng II (2-5\%) pada area Kecamatan Semarang Barat, Gajahmungkur, Semarang Selatan, Candisari, Ngaliyan, dan Gunungpati. Lereng III (15-40\%) terdiri dari wilayah di sekitar Kali Kreo (Kecamatan Gunungpati) dan Kaligarang, sebagian wilayah Kecamatan Mijen (daerah Wonoplumbon), Kecamatan Candisari dan sebagian wilayah Kecamatan Banyumanik, serta. Sedangkan lereng IV (> 50\%) meliputi sebagian wilayah Kecamatan Banyumanik (sebelah tenggara), dan sebagian wilayah Kecamatan Gunungpati, terutama disekitar Kali Garang dan Kali Kripik.
Data lain juga menyebutkan bahwa wilayah Kota Semarang berada pada elevasi antara 0 sampai dengan 348,00 meter di atas permukaan air laut (dpl).

\section{METODOLOGI PENELITIAN}

Penyusunan penelitian ini memiliki beberapa tahapan dalam proses penulisan dan analisanya. Hal ini ditujukan sebagai dasar pengembangan konsep dalam perumusan permasalahan yang akan dianalisa. Tahapan-tahapan tersebut adalah (1) perumusan permasalahan, (2) pengumpulan landasan teori dan data, (3) analisa data, (4) kesimpulan dan rekomendasi.

Metode pengumpulan data dilakukan dengan cara studi literatur dan meninjau lokasi Banjir Kanal Timur untuk melihat potensi penerapan angkutan kapal. Setelah meninjau lokasi maka dilakukan penggambaran denah lalu lintas kapal di sungai dengan memanfaatkan bantuan Google Maps untuk menganalisa dimana halte kapal yang paling sesuai untuk kapal berhenti dan juga sebagai sandaran kapal.

Kajian awal untuk profil Siborat tentang perhitungan berat dan desain kapal. Perhitungan berat menggunakan Hukum Archimedes:

$$
\mathrm{Fa}=\rho \mathrm{f} \times \mathrm{g} \times \mathrm{Vc} .
$$

Fa adalah gaya Archimedes $(\mathrm{N})$, $\rho f$ adalah massa jenis fluida $\left(\mathrm{kg} / \mathrm{m}^{3}\right), \mathrm{g}$ adalah percepatan gravitasi bumi $\left(10 \mathrm{~m} / \mathrm{s}^{2}\right)$ dan $\mathrm{Vc}$ adalah volume benda tercelup (m3). Jika benda terapung, maka $\rho f>\rho b$ dan $\mathrm{Fa}=\mathrm{W}$ dengan $\rho f$ adalah massa jenis fluida $\left(\mathrm{kg} / \mathrm{m}^{3}\right)$ dan $\rho$ b adalah massa jenis benda $\left(\mathrm{kg} / \mathrm{m}^{3}\right)$. Oleh karena itu jika dijabawkan maka: $\mathrm{Fa}=\mathrm{W}$ kapal $+\mathrm{W}$ penumpang, sehingga $\mathrm{W}$ kapal $=\mathrm{Fa}-\mathrm{W}$ penumpang.

Penggambaran dan analisa desain kapal Siborat-Semarang Integrated Boat Rapid Transit terinspirasi dari standar kapal penumpang yang dipakai di negara lain seperti Thailand dan eropa. Penggambaran kapal menggunakan software bantu Google Sketch $U p$ yang menampilkan gambar visual 3 dimensi.

Selain itu analisa dan kajian lainnya meliputi kajian terhadap waktu tempuh, harga, dan lokasi penempatan halte. Estimasi waktu tempuh berdasarkan panjang rute dan 
kecepatan kapal Siborat. Estimasi harga berdasarkan harga transportasi umum yang telah ada di Kota Semarang. Sedangkan penempatan halte didasarkan pada halte Bus Trans Semarang yang telah ada dengan cara diintegrasikan.

\section{HASIL DAN PEMBAHASAN}

Angkutan diyakini sebagai layanan transportasi penumpang oleh sistem perjalanan secara bersama yang telah tersedia untuk digunakan oleh masyarakat umum, Angkutan biasanya dikelola sesuai jadwal, dikenakan biaya untuk setiap perjalanan, dan dioperasikan pada rute yang ditetapkan. Pada Semarang Integrated Boat Rapid Transit (Siborat) ini akan menggunakan dan memanfaatkan jalur sungai karena sebagai upaya untuk mengatasi kemacetan lalu lintas di jalur darat. Namun pada pelaksanaannya sungai tersebut harus diupayakan memenuhi standar transportasi sungai terlebih dahulu.

Kondisi Kota Semarang yang memiliki banyak jenis kendaraan terutama kendaraan umum masih belum secara signifikan menggantikan keberadaan kendaraan pribadi. Hal ini terjadi dikarenakan masyarakat masih merasakan bahwa pelayanan dari kendaraan umum masih kurang cepat walaupun sudah ramah dan banyak peningkatan. Beberapa kekurangan pelayanan kendaraan umum adalah waktu tunggu yang terlalu lama, masih menggunakan jalur yang sama dengan kendaraan pribadi sehingga ketika macet tidak ada bedanya, beberapa kendaraan yang sudah tua dengan kursi yang sudah jelek dan kondisi mesin yang sudah tidak baik.

Pada suatu data disebutkan bahwa setiap hari diperkirakan sebanyak 450 ribu orang keluar dan masuk ke Kota Semarang. Kondisi tersebut tentu membuat ruas jalan menjadi sangat padat. Tingkat pertumbuhan kendaraan bermotor di kota ini pun cukup tinggi sebesar 2,5\% per tahun. Pada kecelakaan lalu lintas masih didominasi kendaraan pribadi sebesar $80 \%$. Sebagai upaya agar tingkat kemacetan menurun, kecelakaan diminimalisir, polusi udara berkurang, dan pelayanan angkutan umum dapat lebih dimaksimalkan maka kondisi sistem transportasi di Kota Semarang perlu segera dibenahi.

\subsection{Profil Siborat}

Semarang Integrated Boat Rapid Transit (Siborat) adalah sebuah inovasi kapal dengan kapasitas 20 penumpang. Perhitungan berat kapal ini menggunakan Hukum Archimedes seperti pada rumus (1). Jika dengan asumsi rata-rata berat penumpang adalah $60 \mathrm{~kg}$ dan volume kapal yang tercelup air adalah $3 \mathrm{~m}^{3}$, maka perhitungan berat kapal sebagai berikut:

$$
\begin{aligned}
\mathrm{Fa} & =\mathrm{W} \text { kapal }+\mathrm{W} \text { penumpang } \\
\mathrm{W} \text { kapal } & =\mathrm{Fa}-\mathrm{W} \text { penumpang } \\
& =(\rho \mathrm{f} \times \mathrm{g} \times \mathrm{Vc})-(20 \times 60) \\
& =(1000 \times 1 \times 3)-(1200) \\
& =1800 \mathrm{~kg} \\
& =1,8 \text { ton }
\end{aligned}
$$

Konsep Siborat ini diharapkan akan dapat terintegrasi pada setiap jalur yang dilalui oleh kendaaran umum yaitu Bus Rapid Transit (BRT) atau Trans Semarang. Konsep rancangan Siborat seperti pada Gambar 2.

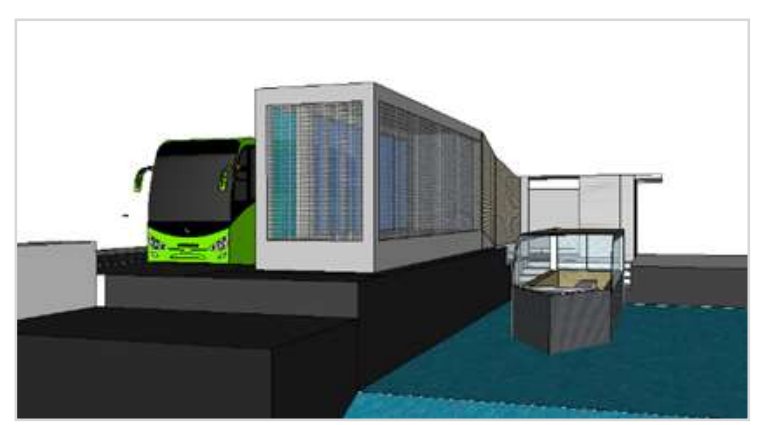

Gambar 2. Siborat-Semarang Integrated Boat Rapid Transit

Gambar 2 mengilustrasikan bahwa kapal Siborat akan berdampingan dengan jaluir bus Trans Semarang. Halte Trans Semarang yang berada disamping Banjir Kanal Barat akan dimanfaatkan secara bersama dengan kapal sungai siborat. Pada saat ini moda transportasi Trans Semarang telah banyak digunakan oleh masyarakat. Trans Semarang juga diyakini telah menjadi solusi pengurangan kemacetan meskipun belum signifikan. Jika Siborat nanti akan bisa terintegrasi dengan Trans Semarang, hal ini akan memudahkan masyarakat yang telah menggunakan siborat sebagai kendaraan bisa berhenti di halte dan langsung berpindah ke bus Trans Semarang untuk melanjutkan perjalanannya. 


\subsection{Analisis penggunaan Siborat \\ 4.2.1. Waktu}

Pada konsep ini Siborat akan beroperasi dari pusat Kota Semarang menuju utara Kota Semarang. Estimasi perjalanan sekitar 20 menit dan dapat memangkas waktu perjalanan dibanding jalur darat. Setiap Siborat akan diberangkatkan sesuai waktunya dengan interval 7 menit. Hal ini juga mengacu pada interval bus Trans Semarang jika normal.

\subsubsection{Harga}

Besarnya biaya yang dikeluarkan untuk menggunakan transportasi Siborat ini harapannya tidak lebih mahal dari transportasi umum kota yang sudah ada seperti Bus Trans Semarang. Siborat ini akan dimasukkan kedalam bagian dari BRT Trans Semarang sehingga nantinya dapat terintegrasi antar satu transportasi dengan yang lainnya. Jika Siborat berpotensi untuk diterapkan maka besarnya tarif ini tentu harus dianalisa berdasarkan anggaran biaya daerah. Bisa dengan subsidi pemerintah atau kerjasama dengan pihak ketiga sebagai penyelenggara.

\subsection{Lokasi peletakan halte Siborat}

Rute yang akan dilalui Siborat diantaranya Majapahit Central Station Jolotundo Station - Masjid Agung Jawa Tengah \& Johar Market - Citarum Station - Kaligawe Station - Tanjung Emas Industry Station seperti pada Gambar 3.
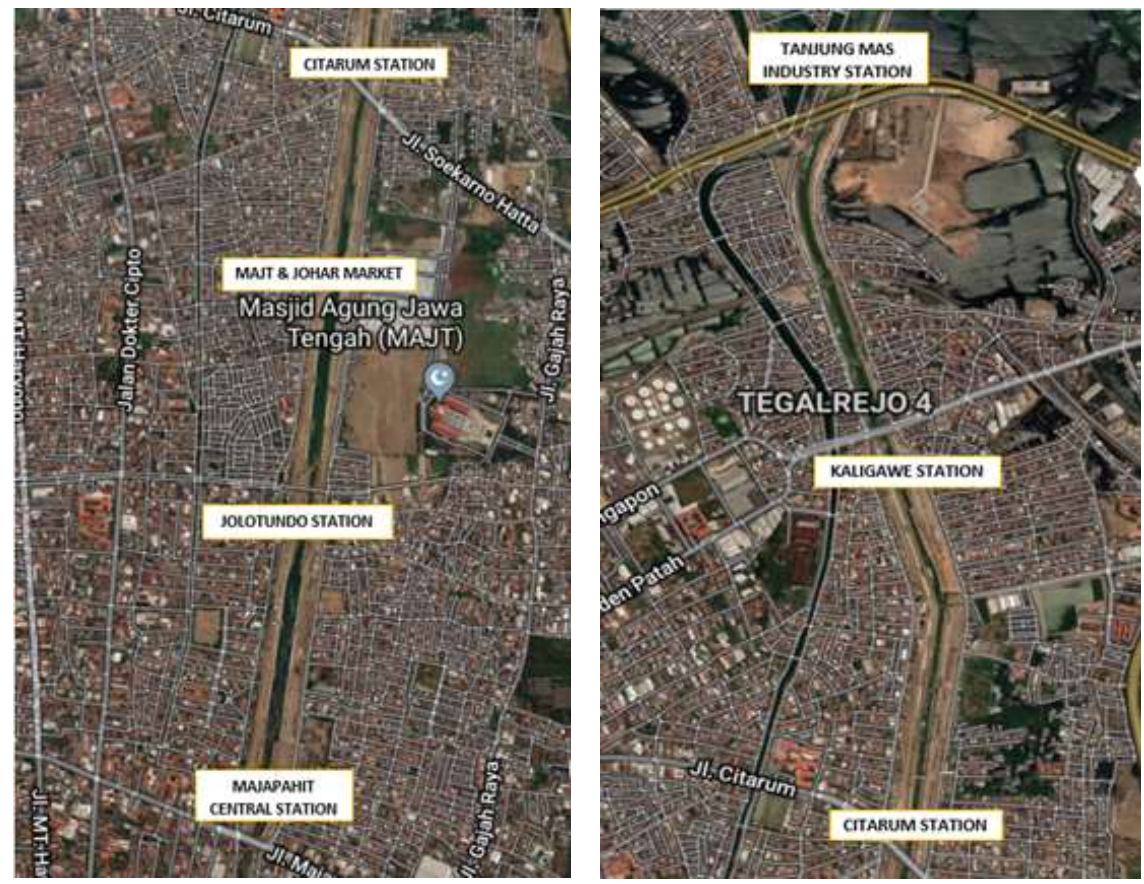

Gambar 3. Halte Siborat-Semarang Integrated Boat Rapid Transit

Siborat menggunakan teknologi sederhana, hanya dengan memanfaatkan sungai yang ada. Siborat dapat dikembangkan melalui riset berkelanjutan. Maka, pembangunan dapat diaplikasikan dengan mudah sebagai alat transportasi di dunia.

\section{KESIMPULAN DAN SARAN}

Siborat-Semarang Integrated Boat Rapid Transit diharapkan masalah kemacetan di Kota Semarang dapat berkurang, karena tersedia moda transportasi baru dengan memanfaatkan sungai Banjir Kanal Timur yang juga terintegrasi dengan moda transportasi yang sudah ada. Siborat-Semarang Integrated Boat Rapid Transit menggunakan teknologi ramah lingkungan sehingga dapat mengurangi dampak negatif transportasi.

Berdasarkan hasil kajian didapatkan profil kapal penumpang Siborat-Semarang Integrated Boat Rapid Transit dengan daya tamping 20 penumpang dan berat 1.8 ton. Siborat diharapkan mudah untuk diaplikasikan karena menggunakan teknologi yang sederhana. Tarif Siborat-Semarang Integrated Boat Rapid Transit diharapkan tergolong murah sehingga terjangkau bagi masyarakat serta efisien karena terintegrasi dengan Trans 
Semarang. Sistem Siborat-Semarang Integrated Boat Rapid Transit dapat dikembangkan lebih lanjut sebagai moda transportasi baru yang dapat menyelesaikan masalah kemacetan pada kota besar di seluruh Indonesia.

Kemacetan di Indonesia khususnya di kota-kota besar semakin tahun semakin meningkat, hal ini sangat merugikan masyarakat dari segi ekonomi dan waktu. Dengan adanya inovasi terbarukan yaitu Siborat-Semarang Integrated Boat Rapid Transit, diharapkan dapat membantu Pemerintah Kota Semarang dalam menyediakan tranportasi yang aman, efisien, dan ramah lingkungan. Sehingga masalah kemacetan dapat terselesaikan dan dapat diterapkan di kota lain.

\section{DAFTAR PUSTAKA}

.[1] B. Sitorus and T. I. H. Sitorus, "Dukungan Transportasi Logistik Dan Daya Saing Indonesia Dalam Menghadapi Masyarakat Ekonomi Asean," J. Manaj. Transp. Dan Logistik, vol. 4, no. 2, p. 137, 2017.

[2] A. Reseda, S. Darsono, and Suharyanto,
Kajian Efektifitas Pengendalian Banjir di DAS Garang. Magister Teknik Sipil Universitas Diponegoro, 2012.

[3] A. Ma'rruf, A. S. Graha, Salamun, and Ismiyati, "Pengembangan Sungai Banjir Kanal Timur Semarang," J. Karya Tek. Sipil, vol. 4, no. 4, pp. 107-120, 2015.

[4] M. N. Sholeh, "Aplikasi Rantai Pasok: Pengadaan Material Konstruksi Antar Pulau," Proceeding SENDI_U, pp. 978-979, 2015.

[5] Badan Pusat Statistik, "Kota Semarang dalam Angka 2016,” 2017.

[6] S. Rahma, D. A. Wijayanti, Ismiyati, and Djoko Purwanto, "Penyediaan Transportasi Umum Masa Depan Di Kota Semarang," J. Karya Tek. Sipil, vol. 3, no. 1, pp. 154-166, 2014.

[7] P. Faktor et al., "Parking di Kawasan Tunjungan dan Blauran Kota Surabaya," vol. 7, no. 2, 2018.

[8] E. Wahyono, B. T. Yuda, and D. Marihandono, Pelayaran Perintis dalam Integrasi Nasional dan Perkembangan Daerah Perbatasan, Terpencil, dan Tertinggal 1974-2012. Jakarta: Universitas Terbuka, 2014. 